\title{
Appendix The Old Avestan Texts
}

I give here an edition of the texts, articulated for reading and with a critical apparatus. Information about manuscripts and readings is drawn from the materials in Geldner's edition for the verse texts and from Narten's for the Yasna Haptanhaiti. I have eliminated the mass of merely orthographical variants and added notice of the most significant modern emendations known to me. From the large number of manuscripts reported by Geldner and Narten I have selected eight as being sufficient to represent the tradition; the best readings transmitted are normally to be found among them. They fall neatly into four families, as follows (Geldner's sigla in square brackets):

$m$ manuscripts copied by Mitrō-Āpān in 1323, namely:

A [J2] = Oxon. Bodl. Ms. Zend c. 1

$\mathrm{B}[\mathrm{K} 5]$

h lost manuscript copied by Hōshāng i Sīyāvakhsh c. 1478, represented by:

C [Mf1], copied in 1741

$\mathrm{D}$ [Pt4], copied in 1780

$s$ manuscripts of the Indian Yasna Sade, notably:

E [H1], not dated

$\mathrm{F}[\mathrm{J} 6], 16$ th-17th century

v manuscripts of the Persian Vendidad Sade, notably:

G [Mf2], copied in 1618

$\mathrm{H}$ [Jp1], copied in 1638

I use the siglum $\omega$ for the consensus of the manuscripts, and dett. (deteriores) for unspecified manuscripts not included in the above selection. $\mathrm{A}^{\mathrm{a}}$ and $\mathrm{A}^{\mathrm{c}}$ mean $\mathrm{A}$ before or after correction.

\section{A. The Verse Texts}

\section{Yasna 27}

13 yaữa ahū vairiiō, ađāa ratuš așaātcīin hacā vanhōuš dazdā manayhō š́iiaoưnanąm anhōuš Mazdāi xšaưrəmcā Ahurāiiā, yim drigubiiō dadaț vāstārəm. 
14 aș̌əm vohū, vahištəm astī:

uštā astī, uštā ahmāi,

hiiat aṣāi vahištāi aṣ̆əm.

\section{Yasna 28}

1 ahiiā yāsā nəmạhā ustāna.zastō rafəơrahiiā, Mainiiōuš, Mazdā, paouruuīm Spəṇtahiiā Aṣ̆ā, vīspōṇg, šiiaoưnā, Vạhōuš xratūm Manạhō yā xšnəuuīšā gōušcā uruuānəm,

2 yō vå, Mazdā Ahurā, pairī.jasāi vohū manạhā, maibiiō dāuuōi ahuuå, astuuatascā hiiațcā manạhō, āiiaptā aṣ̆ât hacā, yāiš rapəṇtō daidīt x x̄āôrē;

3 yō vå Aṣ̆ā ufiiānī Manascā Vohū apaouruuīm Mazdąmcā Ahurəm, yaēibiiō xšaưrəmcā a y̌aonuuamnəm varədaitī Ārmaitiš: ā mōi rafəơrāi zauuōṇg jasatā.

4 yō uruuānom mōn gairē vohū dadē haơrā manayhā, aș̌ǐscā š́iiaoưnanąm vīduš Mazdå Ahurahiiā, yauuat isāi tauuācā, auuat xsāi aēšē Aṣ̆ahiiā.

5 Așāa kat ợā darəsānī, manascā vohū vaēdəmnō gàtūmcā Ahurāi ${ }^{1}$ səuuištāi sraošəm Mazdāi? anā mąưrā mazištom vāurōimaidī xrafstrā hizuuā.

6 Vohū gaidī Manạhā, dāidī Aș̣ā då darəgāiiū ərəšuuāiš tū uxôāiš, Mazdā, Zaraơuštrāi aojōṇghuuat rafənō ahmaibiiācā, Ahurā, yā daibišuuatō duuaēšå tauruuāiiāmā.

7 dāidī, Așāa, tạm aș̌īm, vayhōuš āiiaptā manayhō; dāidī tū, Ârmaitē, Vištāspāi īšom maibiiācā; dås.tū, Mazdā, xšaiiācā, yā vō mąưrā srəuuīmā rādå.

8 vahištəm $̛$ ôā, vahištā, yōm Aṣ̆ā vahištā hazaošəm Ahurəm, yāsā vāunuš narōi Frašaoštrāi maibiiācā yaēibiiascā ît rånhạhōi vīspāi yauuē vạhōuš manayhō.

9 anāiš vå nōiț, Ahurā [Mazdā], ${ }^{2}$ Aș̣ımcā yānāiš zaranaēmā Manascā hiiat vahištom, yōi vō yōiơomā dasəmē stūtąm: yūžōm zəuuištiiånhō; īšō xšaưrəmcā sauuạhąm.

10 at yōṇg așāâtcā vōistā vạhōušcā dāôōṇ manayhō ərəở̄̄ng, Mazdā Ahurā, aēibiiō pərənā āpanāiš kāməm; a vō [xšmaibiiā $]^{3}$ asūnā vaēdā x $x^{\mathrm{V}}$ araiviiiā vaiṇtiiā srauuå.

1 ahurāiiā Gippert

2 [] Andreas-Wackernagel

3 [] Wackernagel 
11 yō āiš aș̆øm ni.pånhē manascā vohū yauuaētāitē, tuuōm, Mazdā Ahurā, frō mā sīšā ơßahmāt vaocańhē mainiiōuš hacā ởā ว̄əånhā, yāiš ā ayhuš paouruiiō bauuat.

\section{Yasna 29}

1 xšmaibiiā gōuš uruuā gərəždā: "kahmāi mā ơßarōždūm? kō mā tašat? à mā aēšəmō hazascā rəmō [ā] hišāiiā dərəš[cā] $]^{4}$ təuuišcā. nōit mōi vāstā xšmat aniiō; aưā [mōi] ${ }^{5}$ sąstā vohū vāstriiā."

2 adā tašā gōuš pərəsat Aș̆øm: "kav̄ā tōi gauuōi ratuš, hiiat hīm dātā xšaiiaṇtō? hadā vāstrā gaodāiiō ơßaxšō: kōm hōi uštā ahurəm, yō drəguuōdəbīš aēšəməm vādāiiōit? ?"

3 ahmāi Așāa, nōit sarəjā, aduuaēšō gauuōi, paitī.mrauuat: “auuaēšąm nōit vīduiiē; yā š́auuaitē ādrōṇg ərəšuuånhō, hātąm huuō aojištō, yahmāi zauuōṇg jimā kərədušā,

4 “Mazdå, saxª̄rō mairištō, yā zī vāuuərəzōi pairī.ciôīt daēuuāišcā maṣ̆iāišscā, yācā varəšaitē aipī.ciờit. huuō vīcirō ahurō: aôā [nō] $]^{6}$ ayhat, yaưā huuō vasat.".

5 a vā ustānāiš ā huuā̄ zastāiš frīnəmnā Ahurāiiā, mō uruuā gōušcā aziiå, hiiat Mazdąm duuaidī frasābiiō: "nōit ərəžəjiiōi frajiiāitiš, nōit fšuiieṇtē drəguuasū pairī?"

6 atō̄ vaocat Ahurō Mazdå vīduuå vafūš viiānaiiā: "nōit aēuuā ahū vistō naēdā ratuš așaātcî̀t hacā;

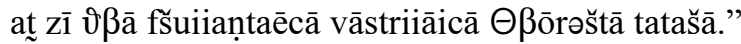

7 tōm āzūtōiš Ahurō mąơrom tašat Așāa hazaošō Mazdå gauuōi xšuuīdəmcā; huuō urušaēibiiō spəntō sāsnaiiā. kas.tē vohū manayhā yō î dāiiāt ōoāuuā marətaēibiiō?

8 “aēm mōi idā vistō, yō nō aēuuō sāsnå gūšatā, Zaravิuštrō Spitāmō: huuō nō mazdå vaštī Așāicā carəkərəơrā srauuaiieńhē, hiiat hōi hudəmə̄m diiāi vaxəơrahiiā."

9 atcā gōuš uruuā raostā, "yō anaēšəm xšąnmōnē rādəm, vācəm nərəš asūrahiiā, yōm ā vasəmī īšā.xšaưrīm. ${ }^{10}$ kadā yauuā huuō ayhat, yō hōi dadat zastauuat auuō?

4 [] Andreas-Wackernagel

5 [] Andreas-Wackernagel: at mōi Bartholomae

6 [ ] Andreas-Wackernagel

7 Kellens-Pirart: ahuuā $D s v$ : ahuuå $m C$

8 Insler: a a jore $\omega$

9 dett.: mazdā $\omega$

10 h F G: xšaป̛rəm $m E$ 
10 “yūžōm aēibiiō, Ahurā, aogō dātā așā xšaưrəmcā auuat vohū manạhā, yā hušəitīš rāmąmcā dāț: azōmcīt ahiiā, Mazdā, ơßąm mōńhī paouruuīm vaēdom."

11 kudā aș̆əm vohucā manō xšaưrəmcā? at mąm aș̆ā ${ }^{11}$ yūžōm, Mazdā, frāxšnənē mazōi magāiiā paitī.zānatā. Ahurā, nū nå auuarō, ōhmā rātōiš yūšmāuuatąm.

\section{Yasna 30}

1 at tā vaxšiiā, išoṇtō, yā mazdā ōà hiiatcīî vīdušē, staotācā Ahurāi $i^{12}$ yesniiācā Vayhōuš Manayhō humązdrā Aṣ̂āiiecā, yā raocōbīš darəsatā uruuāzā.

2 sraotā gōušāiš vahištā, ā vaēnatā sūcā manạhā à varənå vīciơahiiā narōm narəm x $x^{V}$ ax́iiāi tanuiiē parā mazō yånhō, ahmāi [nō] ${ }^{13}$ sazdiiāi baodaṇtō paitī.

3 at tā mainiiū, paouruiiē yā yōmā $x^{\mathrm{V} a f ə n a ̄ ~ a s r u u a ̄ t o m, ~}$ manahi[cā $]^{14}$ vacahicā š́iiaỡanōi hī, vahiiō akəmcā; åscā hudånhō ərəš vī.šiiātā, nōit duždånhō.

4 ațcā hiiat tā hōm mainiiū jasaētom paouruuīm, dazdē gaēmcā ajiiāitīmcā, yaūā[cā] ${ }^{15}$ ayhat apōmom ayhuš: acištō drəguuatąm, at aṣ̆āunē vahištom manō.

5 aiiå mainiuuå varətā yō drəguuå acištā vərəziiō, aș๊əm mainiiuš spōništō, yō xraoždištōṇg asōnō vastē, yaēcā xšnaošən Ahurəm haiơiiāiš š́iiaoûnāiš fraorəț Mazdąm.

6 aiiå nōit ərəš vi.š́iiātā daēuuācinā, hiiat îš ā dəbaomā pərəsəmnōṇg ${ }^{16}$ upā jasat, hiiat vərənātā acištəm manō, at aēšəməm hōṇ.duuārəṇtā, yā bąnaiion ahūm marətānō.

7 ahmāicā xšaưrā jasat manayhā vohū aṣaācā, at kəhrpōm utaiiūitiš dadāt, ārmaitiš ąnmā; aēšąm tōi ā ạhat yav̄ā [aiiạhā] ${ }^{17}$ ādānāiš paouruiiō.

11 Lommel: mā maș̆ā $\omega$

12 ahurāiiā Gippert: ahurahiiā Lommel

13 [] Kuiper

14 [] Bartholomae

15 [] Andreas-Wackernagel

16 Kellens-Pirart: pərəsmanōng fere $\omega$

17 [] Kuiper 
8 atcā yadā aēšąm kaēnā jamaitī aēnayhąm, aț, Mazdā, taibiiō xšaưrom vohū manayhā vōiuuīdāitēe ${ }^{18}$ aēibiiō sastē, Ahurā, yōi Așāai dadən ${ }^{19}$ zastaiiō Drujom.

9 atcā tōi vaēm x́iiāmā yōi īm frašōm kərənāun ahūm, Mazdåscā Ahurånhō ā.mōiiastrā.baranā Așāāā, hiiat haưrā manå buuat yaưrā cistiš ayhat ${ }_{\sim}^{20}$ maēôā.

10 adā zì auuā Drūjō [auuō] buuaitī skəṇdō spaiiaưrahiiā, at āsištā yaojaṇtē ā hušitōiš Vanhōuš Manayhō Mazdå Aṣ̆ax́iiācā, yōi zazəṇtī vayhāu srauuahī.

11 hiiat tā uruuātā sašāôân ${ }^{21}$ yā Mazdå dadāț, maș̆iiånhō,

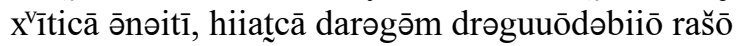
sauuacā aṣ̆auuabiīō, at aipī tāiš ạhaitī uštā.

\section{Yasna 31}

1 tā vō uruuātā maroṇtō aguštā vacå sōṇghāmahī aēibiiō yōi uruuātāiš Drūjō Aṣ̆ahiiā gaēưå vī.mərəṇcaitē, ațiît aēibiiō vahištā yōi zrazdå ạhən Mazdāi.

2 yezī āiš nōit uruuānē aduuā ${ }^{22}$ aibī.dərəštā vax́iiå, at vå vīspōṇg ā <a>iiōi ${ }^{23}$ yaưā ratūm Ahurō vaēdā Mazdå aiiå ąsaiiå, yā așăă hacā juuāmahī.

3 yąm då mainiiū āôrācā așāāā cōiš rānōibiiā xšnūtōm, hiiat uruuātəm cazdōyhuuadəbiiō, tat nō, Mazdā, vīduuanōi vaocā hizuuā ơßahiiā ånhō, yā juuaṇtō vīspōṇg vāuraiiā.

4 yadā Aṣ̆m zouuīm ayhon Mazdåscā Ahurånhō Aș̣icā Àrrmaitī, vahištā išasā manayhā maibiiō xšaưrəm aojōyhuuat, yehiiā vərədā vanaēmā Drujəm.

5 tạ mōi vī.cidiiāi vaocā, hiiat mōi așaā dātā vahiiō, vīduiiē vohū manạhā mōṇcā daidiiāi, yehiiā mā ərəšiš, tācīt, Mazdā Ahurā, yā nōit vā ayhat ạhaitī vā.

6 “ahmāi ạhat vahištom, yō mōi vīduuå vaocāt haiôīm, mąôrəm yim hauruuatātō aș̆ahiiā amərə<ta $>$ tātascā. ${ }^{24}$ Mazdāi auuat xšaƯrəm, hiiat hōi vohū vaxšat manayhā."

\footnotetext{
$18 m:-\mathrm{t} \overline{\mathrm{h}} \mathrm{s} v$

19 dąn Andreas-Wackernagel

20 anhaitī?

21 West: saš́ađā $\omega$

22 det., Insler: aduuå $\omega$

$23<>$ Meillet

$24<>$ Monna
} 
7 yas.tā mantā paouruiiō raocōbīš rōiơßən x $\mathrm{v} a ̄ 0$ rā, huuō xrav̛ßā dąmiš aș̌om, yā dāraiiat vahištom manō; tā, Mazdā, mainiiū uxšiiō, yō ā nūrōmcīt, Ahurā, hāmō. ${ }^{25}$

8 at ởā mōýhī paouruuīm, Mazdā, yazūm stōi manạhā, vayhōuš ptarōm manạhō, hiiat ởā hōm cašmainī [hōṇ] grabəm, haiòīm ${ }^{26}$ aṣ̆ahiiā dąmīm, ayhōuš ahurəm š́iiaovaanaēšū.

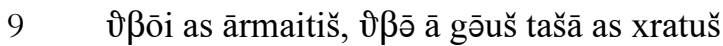
mainiiōušs, ${ }^{27}$ Mazdā Ahurā, hiiat ax́iiāi dadå paưąm vāstriiāt vā ā itē yō vā nōit ạhat ${ }_{\sim}^{28}$ vāstriiō.

10 at hī aiiå fra.uuarətā vāstrīm ax́iiāi fšuiiaṇtəm ahurəm aș̆auuanəm, vayhōuš fš̄óhīm manayhō; nōit, Mazdā, auuāstriiō dauuąscinā humərətōiš baxštā.

11 hiiat nō, Mazdā, paouruuīm gaēơåscā tašō daēnåscā ৩̛ßā manạhā xratūšcā, hiiat astuuaṇtəm dadå uštanəm, hiiat š́iiaoưnācā sōṇghąscā, yaưrā varonōṇg vaså dāiietē,

12 aƯrā vācəm baraitī miơah.uuacå vā ərəš.uuacå vā, vīduuå vā əuuīduuå vā, ahiiā zərədācā manạhācā; ānuš.haxš Ārmaitiš mainiiū pərəsaitē, yaưrā maēôā.

13 yā frasā āuuīšiiā, yā vā, Mazdā, pərəsaētē taiiā, yō vā kasōuš aēnạhō ā mazištąm [a]yamaitē būjom, tā cašmōṇg ơßisrā hārō aibī aṣ̆ā [aibī] vaēnahī vīspā.

14 tā ơßā pərəsā, Ahurā, yā zī ā <aē $>$ itîn ${ }^{29}$ jōṇghaticā, yå išudō dadəntē dāôranąm hacā așāunō yåscā Mazdā drəguuōdəbiiō - yaùā tå ayhən hōṇkərətā hiiat.

15 pərəsā auuat, yā maēnišs, ${ }^{30}$ yō drəguuāitē xšaơrom hunāitī dušš́iiaỡanāi, Ahurā, yō nōit jiiōtūm hanarə vīnastī vāstriiehiiā aēnayhō pasōuš vīrāațcā adrujiiaṇtō.

16 pərəsā auuat, yaūā huuō yō hudānuš dəmanahiiā xšaơrom šōiơrahiiā vā dax́iiōuš vā așā fradaūāiiā spərəzatāa ${ }^{31}$ ơßāuuąs, Mazdā Ahurā - yadā huuō ạhat yā.š́iiaoơnascā.

25 yō [ā] Roth hāmō $C$ v: haomō $m D s$

26 hiơąm Kellens-Pirart; praestat hiđāum

$27 B$ : ma(i)niiūš $s$, -uš $A h v$

28 ayhaitī?

$29<>$ Bartholomae

$30 h v$ : mainiš $m s$

31 Insler: fradavāi asp- $\omega$ 
17 katārōm aṣ̆auuā vā drəguuå vā vərənauuaitē maziiō? vīduuå vīdušē mraotū, mā əuuīduuå aipī dōbāuuaiiat. zdī nō, Mazdā Ahurā, vayhōuš fradaxštā manạhō.

18 mā.ciš aț vō droguuatō mąơrą̧scā gūštā sāsnåscā, ā zị dəmānəm vīsəm vā šōiơrom vā dax́iiūm vā [ā]dāt dušitācā marəkaēcā; aṽā īš sāzdūm snaiơišā.

19 gūštā yō maṇtā aș̆em ahūm.biš vīduuå, Ahurā, ərəž.uxōāi vacayhąm xšaiiamnō hizuuō vasō ơßā āôrā suxrā, Mazdā, vạhāu vīdātā rąnaiiå.

20 yō aiiat t2 $^{32}$ așauuanəm, diuuamnəm hōi aparəm xšaiiō; darəgə̄m āiiū təmạhō, dušx varəò̄̄m, auuaētās vacō, tōm vå ahūm, drəguuaṇtō, š́iiaovaanāiš x $\mathrm{v}$ āiš daēnā naēšaț.

21 Mazdå dadāt ${ }^{33}$ Ahurō hauruuātō amərə<ta $>$ tātascâ $^{34}$ būrōiš ā așax́iiācā x $\mathrm{V}$ āpaiviiiāt xšaưrahiiā sarō $<\mathrm{i}>35$ vayhōuš vazduuarō manayhō, yō hōi mainiiū š́iiaoঠ̂nāišcā uruuāôō.

22 ciơrā 1 hudånhē, yaờnā vaēdəmnāi manạhā; vōhū huuō xšaưrā aș̌om vacạhā š́iiaovanācā haptī. huuō tōi, Mazdā Ahurā, vāzištō ayhaitī astiš.

\section{Yasna 32}

1 ax́iiācā $x^{\mathrm{v} a e ̄ t u s ̌ ~ y a ̄ s a t ̦, ~ a h i i a ̄ ~ v ə r ə z o ̄ n ə m ~ m a t ̦ ~ a i r i i a m n a ̄, ~}$ ahiiā daēuuā mahmī manōi, ${ }^{36}$ Ahurahiiā ưưuazəmā Mazdå: "Ơßōi dūtåyhō ånhāmā, tōṇg daraiiōo ${ }^{37}$ yōi vå daibišəṇtī":

2 aēibiiō Mazdå Ahurō sārəmnō Vohū Manayhā xšaưrāt hacā paitī.mraoț, Așā huš.haxā x xvōnuuātā, "spəṇtąm vō ārmaitīm vạ̄hīm varəmaidī; hā nō ạhat.."

3 at yūš daēuuā vīspånhō Akāt Manayhō stā ciơrəm, yascā vå maš yazaitē, Drūjascā Pairimatōišcā; š́iiaomąm aipī daibitānā, yāiš asrūdūm ${ }^{38}$ būmiiå haptaiôē,

4 yāt yūš tā fra.mīmavoā, yā mașiiiā acištā daṇtō vaxšəṇtē daēuuō.zuštā, vayhōuš sīždiiamnā manayhō, Mazdå Ahurahiiā xratōuš nasiiaṇtō Aṣ̂āatcā.

32 āiiat $m h v$ : dāiiat $s$

33 dadat $A^{a} B^{a} s G$

$34<>$ Andreas-Wackernagel

$35<>$ West

36 mnōi Andreas-Wackernagel

37 Humbach: dāraiīō $\omega$

38 vel ā srūdūm 
5 tā dəbənaotā maș̌īm hujiiātōiš amərə<ta $>$ tātascā, ${ }^{39}$

hiiat vå akā manāhā yōng daēuuōng akascā mainiiuš, akā š́iiaoûnəm vacạhā yā fra.cinas drəguuaṇtəm xšaiiō.

6 pourū aēnå ōnāxštā yāiš srauuahiieitī, yezī tāiš aôā, hātā.marānē Ahurā, vahištā vōistā manạhā; ৩̛ßahmī vō, ${ }^{40}$ Mazdā, xšaưrōi Așaāiiecā ${ }^{41}$ sōnghō vī.dąm.

7 aēšąm aēnạhąm naē.cīî vīduuå aojōi hādrōiiā, yā jōiiā sōṇghaitē, ${ }^{42}$ yāiš srāuūi xvaēnā aiiạhā, yaēšąm tū, Ahurā, irixtəm, Mazdā, vaēdištō ahī.

8 aēšąm aēnạhąm Vīuuạhušō srāuuī Yimascīt, yō maṣiiōṇg cixšnušō ahmākōṇg gōuš ${ }^{43}$ bagā $x^{V}$ ārəmnō. aēšąmcīt ā ahmī ơßahmī, Mazdā, vīciơōi aipī.

9 dušsastiš srauuå mōroṇdaț, huuō jiiātōuš sōṇghanāiš xratūm; ${ }^{44}$ apō mā īštīm [apa]yaṇtā bərəxóąm hāitīm Vayhōuš Manayhō. tā uxōā mainiiōuš mahiiā, Mazdā, Aṣ̆āicā yūšmaibiiāa ${ }^{45}$ gərəzē.

10 huuō mā nā srauuå mōroṇdaț, yō acištəm vaēnańhē aogədā gąm ašibiiā huuarəcā, yascā dāôōṇg drəguuatō dadāt, yascā vāstrā vī.uuāpat, yascā vadarō vōiždat aṣ̆āunē.

11 taēcīi mā mōroṇdən jiiōtūm, yōi drəguuaṇtō ${ }^{46}$ mazbīš cikōitərəš ạไhīšcā ạhauuascā apaiieitī raēxənayhō vaēdəm, yōi vahištāt aṣ̆āunō, Mazdā, rārəšiiąn manayhō.

12 yā råyhaiion srauuayhā vahištāt š́iiaovanāt marətānō, aēibiiō Mazdå akā mraot, yōi gōuš mōrəṇdən uruuāxš.uxtī jiiōtūm, yāiš grōhmā aș̆āt varətā Karpā xšaưrəmcā īšanąm Drujəm:

13 yā $\bar{a}^{47}$ x̌aưrā grōhmō hīšasat Acištahiiā dəmānē Manạhō, ạhōuš marəxtārō ahiiā, yaēcā, Mazdā, jīgərəzat kāmē ơßahiiā mąưrānō dūtīm, yō īš pāt darəsāa Aṣ̆ahiiā.

14 ahiiā grōhmō ā.hōiôōi nī Kāuuaiiascīt xratūš [nī] dadat varəcāhīcā fraidiuuā, hiiat vīsōṇtā drəguuaṇtom auuō, hiiatcā gāuš jaidiiāi mraō̄, yō dūraošom saocaiiat †auuō. ${ }^{48}$

$39<>$ Monna

40 vī $m$

41 Kellens-Pirart: aṣ̆aēcā $m h$ : aṣ̆āicā $s v$

42 sōnnghaitī $s$

43 Andreas-Wackernagel: gāuš $\omega$

$44 m h v$ : xratū $s$

45 xšmaibiiā Kellens

46 D s H: droguuatō $m C$

47 yāiš $B$ 
15 anāiš ā vī.nōnāsā yā Karəpōtåscā Kəuuītåscā. auuāiš aibîn ${ }^{49}$ yōṇ daiṇtî, nōit jiiātōuš xšaiiamnōṇ. vasō, tōi ābiiā bairiiåṇtē Vayhōuš ā dəmānē Manạhō.

16 hamōm tat vahištācīt, yō ušuruiiē siiascīt dahmahiiā xšaiiąs, Mazdā Ahurā, yehiiā mā aiōīšcīt duuaēōā. hiiat aēnaýhē drəguuatō, ōəānū išiiōng tạhaiiā. ${ }^{50}$

\section{Yasna 33}

1 yaūā āiš, iŪā varəšaitē, yā dātā ayhōuš paouruiiehiiā ratuš ${ }^{51}$ š́iiaoônā razištā drəguuataēcā hiiatcā așāunē yex́iiācā hōm.iiāsaitē miơahiiā yācā hōi ārəzuuā.

2 at yō akəm drəguuāitē vacayhā vā at vā manayhā zastōibiiā vā varəšaitī, vạhāu vā cōiơaitē astīm, tōi vārāi ${ }^{52}$ rādəṇtī, Ahurahiiā zaošē Mazdå.

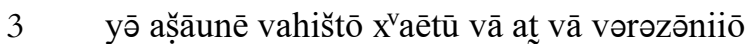
airiiamnā vā, Ahurā, vīdąs vā ơßaxšanhā gauuōi, at huuō Aṣ̆ahiiā ạhat Vayhōušcā vāstrē Manayhō.

4 yō ơßat, Mazdā, asruštīm akəmcā manō yazāi apā x'aētōušcā tarōmaitīm vərəzōnax́iiācā nazdištąm Drujəm airiiamnascā nadəntō gōušcā vāstrāt acištom maṇtūm,

5 yas.tē vīspō.mazištom sraošəm zbaiiā auuạhānē apānō darəgō.jiiāitīm ā xšaưrəm vạhōuš manayhō, ašăta ā ərəzūš paôō, yaēšū Mazdå Ahurō s̆́aēitī,

6 yō zaotā așā ərəzuš, huuō mainiiōuš ā vahištāt kaiiā ahmāt, auuā manayhā yā vərəziieidiiāi mantā vāstriiā, tā tōi iziiā, Ahurā Mazdā, darštōišcā hōm.parštōišcā.

7 ā mā [ā] așā vohū manayhā, yā sruiiē parō magāunō; àuuiš nå aṇtarə hōṇtū nəmax ${ }^{V}$ aitīš ciơrå rātaiiō.

8 frō mōi [fra]uuōizdūm arəơā tā, yā vohū š́iiauuāi manạhā, yasnəm, Mazdā, xšmāuuatō, at vă $\bar{a}^{-53}$ așā staomiiā vacå. dātā vō amərətåscā utaiiūitī hauruuātās draonō.

48 ex versu priore male repetitum: fort. haomøm

$49 m h: \operatorname{aip} \bar{i} s v$

50 fort. ånhaii(a)ā

51 ratuš $A$ s: ratūš $B h v$

52 vārāiiā Bartholomae

$53 F v$ : vå $m h E$ 
9 at tōi, Mazdā, tōm mainiiūm aṣ̆ā uxšaiiaṇtom ${ }^{54}$ sarəidiiaiiå X⿳āơrā maēôā maiiā vahištā barətū manayhā: aiiå ārōi hākurənəm, yaiiå haciṇtē uruuąnō.

10 vīspås tå ${ }^{55}$ hujītaiiō yå zī ånharō yåscā həṇtī yåscā, Mazdā, bauuaiṇtī, ơßahmī hīš zaošē ā.baxšōhuuā; vōhū uxšiiā manayhā xšaưrā așaācā uštā tanūm.

11 yō souuištō ahurō Mazdåscā, Ārmaitišcā Aṣ̆əmcā frādaț.gaēÙom Manascā Vohū Xšaưromcā, sraotā mōi, mərəždātā mōi ādāi kahiiācīi ${ }^{56}$ paitī.

12 us mōi [uz]ārəšuuā, Ahurā, ārmaitī təuūīšìm dasuuā, spōništā mainiiū, Mazdā, vayhuiiā zauuō ādā, aṣ̆ā hazō ōmauuat, vohū manayhā fsøratūm.

13 rafəơrāi, vouru.cašānē, dōiš̄i mōi yā vō ā bifrā, ${ }^{57}$ tā xšaưrahiiā, Ahurā, yā vạhōuš așišs manayhō; frō, spəntā Ārmaitē, aṣ̆ā daēnå [fra]daxšaiiā.

14 at rātąm Zaravušstrō tanuuascīt x x ax́iiå uštanəm dadāitī, pauruuatātom manayhascā vạhōuš Mazdāi š́iiaoưnahiiā Aṣ̆āiiācā uxôax́iiācā, sraošəm xšaưrəmcā.

\section{Yasna 34}

1 yā š́iiaoưnā, yā vacayhā, yā yasnā amərətatātəm ašəmcā taibiiō dånhā, Mazdā, xšaơromcā hauruuātātō, aēšąm tōi, Ahurā, ōhmā pourutəmāiš dastē.

2 ațcā 1 tōi manạhā mainiiōušcā vạhōuš vīspā dātā spəntax́iiācā nərəš šiiaoơnā, yehiiā uruuā așāa hacaitē, pairi.gaēôē xšmāuuatō vahmē, Mazdā, garōbīš stūtąm.

3 at tōi miiazdəm, Ahurā, nəmanhā Aṣ̄āicā dāmā gaēưå vīspå ā xšaưrōi, yå vohū ơraoštā manayhā; ārōi zī hudånhō vīspāiš, Mazdā, xšmāuuasū sauuō.

4 at tōi ātrōm, Ahurā, aojōyhuuaṇtom aṣ̆ā usōmahī aš.ǐšìm ōmauuaṇtom stōi rapaṇtē ciơrā.auuạhəm, at, Mazdā, daibišiiaṇtē zastā.ištāiš dərəštā.aēnayhəm.

54 West: aṣ̆aoxšaiiaṇtå $\omega$

55 West: vīspå stōi $\omega$

$56 D$ E: kahiiāicīt $B F v$

57 West: abifrā $\omega$ 
5 kaț vō xšaÛrəm, kā īštiš š́iiaoônāi, ${ }^{58}$ Mazdā, hiiat ā vō ahmīi, ${ }^{59}$ așā vohū manayhā Ưrāiiōidiiāi drigūm yūšmākəm? "parō vå vīspāiš [parō] vaoxmā daēuuāišcā xrafstrāiš maș̌iiāišcā."

6 yezī aưā stā haiờim, Mazdā Aṣā Vohū Manayhā, at tat mōi daxštom dātā ahiiā ạhōuš vīspā maēôā, yaưā vå yazəmnascā uruuāidiiå stauuas aiien̄i paitī.

7 kuƯrā tōi arədrā, Mazdā, yōi vạhōuš vaēdənā manạhō sōṇghūš raēxnå aspōṇcīt sādrācīt caxraiiō ušəurū? naē.cīm tōm aniiōm yūšmat vaēdā aṣ̆â; aûā nå Ûrāzdūm.

8 tāiš zī nå šiiaoûnāiš biiaṇtī, yaēšū as pairī pourubiiō iơiiejō, hiiat aš.aojå nāidiiånhəm, ơßahiiā, Mazdā, ąstā uruuātahiiā; yōi nōit aṣ̆əm mainiiaṇtā, aēibiiō dūirē vohū as manō.

9 yōi spəntąm ārmaitīm ơßahiiā, Mazdā, bərəxôąm vīdušō dušš́iiaờnā auua.zazat vạhōuš ouuistī manạhō, aēibiiō maš Aș̆ā siiazdat, yauuat ahmat a $^{60}$ aurunā xrafstrā.

10 ahiiā vạhōuš manạhō šiiaoùnā vaocat "gərəbąm” huxratuš spəṇtąmcā Ārmaitīm, dąmīm vīduuå hiợam ${ }^{61}$ Așahiiā, tācā vīspā, Ahurā, ơßahmī, Mazdā, xšaưrōi yā $\overline{a ̀}^{62}$ vōiiaưrā.

11 at tōi ubē hauruuåscā $x^{V}$ arəơāiiā amərətatåscā: Vayhōuš xraข̛ß $\bar{a}^{63}$ Manayhō Aṣ̆ā mat Ārmaitiš vaxšt utaiiūitī touuīšši: tāiš ā, Mazdā, †vīduuaēšąm ơßōi ahī ${ }^{64}$

12 kat tōi rāzarō, kat vašī, kat vā stūtō kat vā yasnahiiā? srūidiiāi, Mazdā, frā.uuaocā, yā vī.dāiiāt aș̌ǐš rāšnąm; sīšā nå aṣ̆ā paōō vayhōuš xªētōṇg manayhō:

13 tōm aduuānəm, Ahurā, yōm ${ }^{65}$ mōi mraoš vayhōuš manạhō, daēnå saošiiaṇtąm yā hū.kərətā așẫẫcit ${ }^{66}$ uruuāxšat hiiat couuištā hudåbiiō mīždəm, Mazdā, yehiiā tū daơrəm.

14 tat zì, Mazdā, vairīm astuuaitē uštānāi dātā vayhōuš š́iiaoưnā manạhō, yōi zị gōuš vərəzōnē aziiå: xšmākąm hucistīm, Ahurā, xratōuš aṣaā frādō vərəzōnā.

$58 m h$ F: - Unā E: - ชิnāiš $v$

59 West: yaưā vā hahmī fere $\omega$ (ahmī $F$ dett.)

60 ahmāt $D$

$61 m$ C: haiơąm $D s$ v: haiviiiąm? Geldner

62 West: xšaưrōi ā $m h s$, xšaưrōiiā $v$

$63 B$ : xsaưrā $A h s v$

64 vīduuaēšəm Insler, ৩७ß̄iiiahī Lommel; $c f$. $\$ 300$

$65 s v:$ yō $m h$

$66 m$ D: aṣ̆ācīt $C s v$ 
15 Mazdā, at mōi vahištā srauuåscā š́iiaovanācā vaocā, tā tū vohū manayhā așaācā išudəm stūtō:

xšmākā xšaưrā, Ahurā, frašōm vasnā haiviiiōm då ahūm.

\section{Yasna 43}

1 uštā ahmāi, yahmāi uštā kahmāicīț, vasō.xšaiiąs Mazdå dāiiāt Ahurō. utaiiūitī təuū̄šsi ${ }^{67}$ gatōi vasmī, aș̌əm dərəidiiāi: taț mōi då, Ârmaitē, rāiiō aṣ̌ǐs̆, vạhōuš gaēm manayhō.

2 ațcā ahmāi vīspanąm vahištom $x^{V}$ āơrōi ā nā x $x^{\mathrm{V}}$ ōôrom daidītā, ơßā ciciơßā spōništā mainiiū, Mazdā, yå då aṣ̆ā vayhōuš māiiå manayhō vīspā aiiārō darəgō.jiiātōiš uruuādạhā.

3 at huuō vạhōuš vahiiō nā aibī.jamiiāt, yō nå ərəzūš sauuayhō paưō sīšōit ahiiā ayhōuš astuuatō manayhascā, haiơiiō̄ng āstīšs, yōng à.š́aēitī Ahurō, arədrō ởāuuąs huzōṇtuš spəntō, Mazdā.

4 at ởā mōṇghāi taxməmcā spəṇtəm, Mazdā, hiiat tā zastā, yā $\bar{a}^{68}$ tū hafš̃ auuå yå då aṣ̆1̌s̆ drəguuāitē așāunaēcā ৩̛ßahiiā garəmā āôrō așāa.aojayhō, hiiat mōi vayhōuš hazō jimat manayhō.

5 spəntom at ơ hiiat ởā ạhōuš ząōōi darəsəm paouruuīm, hiiat då šiiaoûnā mīždauuąn yācā uxōā, akōm akāi, vay'hīm aș̌īm vạhaouuē ơßā hunarā dāmōiš uruuāēsē apōmē.

6 yahmī spəṇtā ởā mainiiū uruuaēsē jasō mazdå ${ }^{69}$ xšaưrā, ahmī vohū manayhā, yehiiā šiiaoûnāiš gaēòå aṣā frādəntēe, aēibiiō ratūš sōṇghaitī Ārmaitiš ơßahiiā xratōuš, yōm naē.ciš dābaiieitī.

7 spəntom at ợā, Mazdā, mōńhī, Ahurā, hiiat mā vohū pairī.jasat manayhā

67 touūī̌s $s:-$ šīm $m h v$

68 fort. yā $<\overline{\mathrm{a}}>$, cf. $\$ 300$

$69 A$ : mazdā $B s v$ 
pərəsațcā mā, "ciš ahī? kahiiā ahī?

kav̄ā aiiarō daxšārā ${ }^{70}$ frasaiiāi $^{71}$ dīšā

aibī ơßāhū gaēōāhū tanušicā?",72

8 at hōi aojī "Zarav̛uštrō" paouruuìm;

"haiviiiō duuaēšå hiiat isōiiā drəguuāitē, at aș̆āunē rafonō x́iiōm aojōyhuuat,

hiiat à būštīš vasas.xšaưrahiiā diiā yauuat ā $̛$ $ß \bar{a}$, Mazdā, staomī ufiiācā."

9 spəṇtəm at ởā, Mazdā, mōñhī, Ahurā, hiiat mā vohū pairī.jasat manayhā:

ahiiā frasōm "kahmāi vīuuīduiiē vašî̀?"

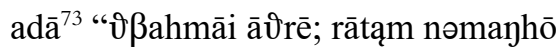
aṣ̆ahiiā mā, yauuat isāi, maniiāi."

10 at tū mōi dāiš aș̆əm, hiiat mā zaozaomī; ārmaitī hacimnō ît ā <a>rəm, ${ }^{74}$ pərəsācā nå, yā $\bar{a}^{75}$ tōi ōhmā parštā (parštōm zī ởā yađ̀ənā tat †ōmauuaṇtąm), ${ }^{76}$ hiiat ৩̛ $\beta \bar{a}$ xšaiiąs aēšəm ${ }^{77}$ diiāt ōmauuaṇtəm.

11 spəṇtəm at ởā, Mazdā, mōñhī, Ahurā, hiiat mā vohū pairī.jasat manayhā, hiiat xšmā uxôāiš dīdaińhē paouruuīm (sādrā mōi sąs maṣ̆iiāšū zrazdāitiš) taț vərəziieidiiāi, hiiat mōi mraotā vahištəm;

12 hiiatcā mōi mraoš "aș̆əm jasō” frāxšnənē,

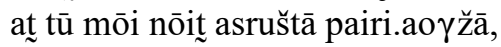
uz.irəidiiāi parā hiiat mōi ā jimat Sraošō Aṣ̌ị mązā.raiiā hacimnō, yâa $\bar{a}^{78}$ ī aṣ̆ǐš rānōibiia ${ }^{79}$ sauuōi [vī]dāiiāț.

13 spəntəm at ởā, Mazdā, mōñhī, Ahurā, hiiat mā vohū pairī.jasat manayhā

\footnotetext{
70 daxšārō Insler

71 fərasiiāi $m$

72 tanušucā Bartholomae: tanuuicā Insler

73 adā Insler, aōā $A$ : at à ceteri

$74<>$ Bartholomae

75 fort. $y \bar{a}<\overline{\mathrm{a}}>$, cf. $\$ 300$

76 ōmauuatąm $C$ v: fort. išoṇtąm

$77 h v$ : aēšs(ə)məm $m s$

78 yō $m$

$79 C$ dett.: rānōibiiō $m D s v$
} 
arəปิā vōizdiiāi kāmahiiā tōm mōi dātā darəgahiiā yaoš, yōm vå naē.ciš dāršt itē, vairiiå stōiš, yā ơßahmī xšaưrōi vācī.

14 hiiat nā friiāi vaēdəmnō isuuā daidīt, maibiiō, Mazdā, tauuā rafənō frāxšnənəm, hiiat v̛ßā xšaưrā aṣ̆āț hacā fr $<\mathrm{a}>$ ąštā, uz.iroidiiāi azō sardanå sōṇghahiiā mat tāiš vīspāiš yōi tōi mąưrå marəṇtī.

15 spoṇtom at ởā, Mazdā, mōńhī, Ahurā, hiiat mā vohū pairī.jasat manayhā: daxšat ušiiāi tušnā.maitî̌ vahištā. nōit nā pourūš droguuatō x́iiāt cixšnušō; at tōi vīspōṇg aṇgrōṇg aṣ̆āunō ādarō.

16 at Ahurā, huuō mainiiūm Zaraơuštrō vorəṇtē, Mazdā, yas.tē cišcā spōništō. astuuat Aș̆øm x́iiāt uštānā aojōyhuuat; xº̄ng darosōi xšaưrōi ${ }^{80}$ x́iiāt Ã Armaitiš; aș̄īm ${ }^{81}$ š́iiaoơnāiš vohū daidīit manạhā.

\section{Yasna 44}

1 tat ̛̛ $\beta \bar{a}$ pərəsā, ərəs̆ mōi vaocā, Ahurā, nəmayhō ā, yaūā nəmō xšmāuuatō; Mazdā, friiāi ơßāuuąs sax́iiāt mauuaitē. at nō așāa friiā dazdiiāi hākurənā, yaưa nō à vohū jimaț manayhā.

2 tat ơ kav̀ā ayhōuš vahištahiiā paouruuīm kāôō sūidiiāi yō ̄ pait $<\overline{1}>$ išât? huuō zī așā spəntōō irixtom vīspōibiiō hārō mainiiū ahūm.biš uruuāôō, Mazdā.

3 tat ởā pərəsā, ərəš mōi vaocā, Ahurā: kas.nā ząūā ptā Aṣ̆ahiiā paouruiiōo $?^{82}$ kas.nā $x^{\mathrm{V} \partial ̄ n g ~ s t r o ̄ m c a ̄ ~ d a ̄ t ~ a d u u a ̄ n ə m ? ~}$ kō yā $\bar{a}^{83}$ må uxšiieitī nərəfsaitī ৩̛ $\beta$ at? tācî̀, Mazdā, vasmī aniiācā vīduiiē.

80 fort. xšaưrā

$81 m h v$ : aṣ̆em $s$

82 paouruiiē $m$

83 fort. yā $<\bar{a}>$, cf. $\$ 300$ 
4 tạ ởā pərəsā, ərəš mōi vaocā, Ahurā:

kas.nā dərətā ząmcā adō nabåscā

auua.pastōišs? kō apō uruuāråscā?

kō vātāi ${ }^{84}$ duuąnmaibiiascā yaogot āsū?

kas.nā vạhōuš, Mazdā, dąmiš manạhō?

5 tat ởā pərəsā, orəš mōi vaocā, Ahurā:

kō huuāpå raocåscā dāt təmåscā?

kō huuāpå x $x^{\mathrm{V} a f n ə m c a ̄ ~ d a ̂ ̀ t ~ z a e ̄ m a ̄ c a ̄ ? ~}$

kō yā ušå arōm.piơßā xšapācā,

yå manaoưrīš cazdōyhuuaṇtəm arəơahiiā?

6 tat ởā pərəsā, orəš mōi vaocā, Ahurā:

yā fra.uuaxšiiā yezī tā aôā haiviiiā, "aș̆əm šiiaoưnāiš dəbązaitī ārmaitiš, taibiiō xšaưrəm vohū cinas manayhā," kaēibiiō azīm rāniiō.skərəitīm gąm tašō?

7 tạ ởā pərəsā, ərəš mōi vaocā, Ahurā: kō bərəxठąm tāšt xšaưrā mat ārmaitīm? kō uzəmōm cōrot viiānaiiā puƯrəm piơrēe azōm tāiš ơßā fraxšnī auuāmī, Mazdā, spəntā mainiiū vīspanąm dātārəm.

8 tat ơßā pərəsā, ərəš mōi vaocā, Ahurā: məṇ.dāidiiāi yā tōi, Mazdā, ādištiš yācā vohū uxōā frašī manayhā yācā aṣ̆ā ayhōuš arōm vaēidiiā: ${ }^{85}$ kā mō uruuā vohū uruuāxšat ā.gmatā?

9 tat ởā pərəsā, ərəš mōi vaocā, Ahurā: kaưā mōi, yąm yaoš daēnąm [yaož]dānē, tąm $^{86}$ hudānaoš paitiš sax́iiāt xšaưrahiiā ərəšuuā xšav̛rā, ôßāuuąs aš.īštiš, Mazdā, hadəmōi aṣ̆ā vohucā š́iiąs manayhā?

10 tat tąm daēnąm, yā hātąm vahištā (yā mōi gaēơå aṣā frādōit hacōmnā), ārmatōiš uxōāiš šiiaoûnā ərəš daidiiat? max́iiå cistōiš ơßā îštiš usōn, Mazdā.

11 tat ởā pərəsā, ərəš mōi vaocā, Ahurā: kaป̄ā tōṇg ā vī.jōmiiāt ārmaitiš,

$84 m C v$ : vāe.tàiı̌ $D s$

$85 m C$ : -diiāi $D E v$, - óiiāi $F$

86 West: yąm $\omega$ 
yaēibiiō, Mazdā, ơßōi vaš́iietē daēnā? azōm tôi àiš paouruiiō ${ }^{87}$ fra.uuōiuuīdē; vīspōṇg aniiōnng mainiiōuš spasiiā duuaēšanhā.

12 tat ช̛̣ā pərəsā, ərəš mōi vaocā, Ahurā: kō aș̆auuā, yāiš pərəsāi, drəguuå vā? katārōm à, aiiōm ${ }^{88}$ vā huuō vā angrōe ? "yō mā drøguuå ơßā sauuā paitī.ərətē ciiayhat, huuō, nōit aiiōm, angrō mainiietē."

13 tat ợā pərəsā, ərəš mōi vaocā, Ahurā: kaưā Drujəm nīš ahmat ā [n̄̄̌s] nāšāmā tōṇg ā auuā, yōi asruštōiš pərənånhō nōit aṣ̆ahiiā ā.dīuuiieiṇtī hacōnāa, ${ }^{89}$ nōit frasaiiā vayhōuš cāxnarō manayhō?

14 tat ợā pərəsā, ərəš mōi vaocā, Ahurā: kav̛a Aș̣āi $i^{90}$ Drujōm diiąm zastaiiō, nī hīm mərąždiiāi ơßahiiā mąưrāiš sōṇghahiiā, ōmauuaitīm sinąm dāuuōi drəguuasū, ā īš duuafšōṇg, Mazdā, [ā] nāšē ąstąscā?

15 tat ৩̛ßā pərəsā, ərəš mōi vaocā, Ahurā: yezī ahiiā așāa pōi maț, xšaiiehī, hiiat hōm spādā anaocanhā jamaētē auuāiš uruuātāiš yā tū, Mazdā, dīdərəžō, kựrā aiiå, kahmāi vananąm dadå?

16 tat ợā pərəsā, ərəš mōi vaocā, Ahurā: kô vərəƯrəm.jā ởā pōi sōnghā, yōi həṇtīciơrā mōi dąm—ahūm.bišs? ratūm cīždì at hōi vohū sraošō jaṇtū manayhā, Mazdā, ahmāi yahmāi vaš̄i kahmāicītu.

17 tạ ởā pərəsā, ərəš mōi vaocā, Ahurā: kađ̛ā [Mazdā] ${ }^{91}$ zarəm carānī hacā xšmat āskəitīm xšmākąm, hiiatcā mōi x́iiāt vāxš aēšō sarōi būždiiāi hauruuātā amərətātā auuā mąưrā, yō rāồmō așaãt hacā?

18 tat ợā pərəsā, ərəš mōi vaocā, Ahurā: kađ̛a aṣ̆ā tat mīždəm hanānī,

$87 s v$ : p(a)ouruiiē $m h$

88 West: angrō $\omega$

$89 D$ : hacōmnā (ex 10c) C s, -imnā $m$

90 așā $m D H$

91 [] West 
dasā aspå aršənuuaitīš uštrəmcā, hiiat mōi mazdā api.uuaitī, hauruuātā amərətātā, yaưā hī taibiiōô ${ }^{92}$ dånhā?

19 tat ơßā pərəsā, ərəš mōi vaocā, Ahurā: yas.tat mīždəm hanəṇtē nōit dāitī, yō ît ahmāi ərəž.ux $\bar{\sim}^{93}$ nā dāitē, kā tōm ahiiā maēniš ąsat ${ }^{94}$ paouruiiēè? vīduuå auuąm, yā īm ąsat ${ }^{95}$ apōmā.

20 ciờnā, Mazdā, huxšav̛rā daēuuā ånharōat ît pərəsā-yōi piš́iieiṇtī aēibiiō kąm, yāišs gąm Karəpā Usixšcā aēšmāi dātā, yācā Kauuā ąnmōnē ${ }^{96}$ urūdōiiatā? nōit hīm mīzōn aṣ̆ā vāstrəm frādaiúhē.

\section{Yasna 45}

1 at fra.uuaxšiiā: nū gūšōdūm, nū sraotā, yaēcā asnāt yaēcā dūrāt išav̄ā;

nū ìm vīspā, ciơrō zî, maz.dånhōdūm. nōit daibitīm dušsastiš ahūm mərąš́iiāt akā varənā, drəguuå hizuuā $\bar{a}^{97}$ à.uuərətō.

2 at fra.uuaxšiiā ạhōuš Mainiiū paouruiiē, yaiiå spaniiå ūitī mrauuat yōm aṇgrəm: "nōit nā manå, nōit sōṇghā, nōit xratauuō, naēdā varənā, nōit uxōā, naēdā š́iiaoûnā, nōit daēnå, nōit uruuąnō hacaiṇtē."

3 at fra.uuaxšiiā ạhōuš ahiiā paouruuīm, yā $\bar{a}^{98}$ mōi vīduuå Mazdå vaocat Ahurō. yōi īm vō nōit iưāâ mąưrəm varəšəṇtī yaūā īm mōnāicā vaocacā, aēibiiō ạhōuš auuōi ạhat apōməm.

4 at fra.uuaxšiiā ayhōuš ahiiā vahištom așāt hacā; Mazdå ${ }^{100}$ vaēdā yō īm dāt,

$92 C D^{c}$ G: taēibiiō $m D^{a} s H$

$93 C v$ : ərəžuxōāi $m D s$

94 Schwyzer: anhat $\omega$

95 Schwyzer: anhat $\omega$

96 ąmōnī $H$, ąnmōnī Geldner

97 dett.: hizuuå $m h s v$ : fort. hizū vāuuərətō

98 F: yąm $m h$ E v: yōm Humbach

$99 m D v$ : aป̄ā $C s$ 
ptarōm Vayhōuš varəzaiiaṇtō Manayhō;

at hōi dugədā huš́iiaoưnā Ȧ̀rmaitiš.

nōit dißžaidiiāi vīspā.hišas Ahurō.

5 at fra.uuaxšiiā, hiiat mōi mraot spontōtomō, vacō srūidiiāi hiiat marətaēibiiō vahištəm;

yōi mōi ahmāi sraošəm dąn caiiascā, upā.jimən hauruuātā amərətātā:

vayhōuš mainiiōuš š́iiaoûnāiš mazdå Ahurō.

6 at fra.uuaxšiiā vīspanąm mazištəm, stauuas așā, yō hudå yōi həṇtī:

spoṇtā mainiiū sraotū Mazdå Ahurō.

yehiiā vahmē Vohū frašī Manayhā,

ahiiā xratū frō mā sāstū vahištā.

7 yehiiā sauuā išåṇtī rādayhō

yōi zī juuā ånharəcā buuaṇticā-

amərətāitī așāunō uruuā aēšō

utaiiūtā, yā nərąš sādrā drəguuatō;

tācā xšaưrā Mazdå dąmiš Ahurō-

8 tōm nō staotāiš nəmạhō ā vīuuarəšō

nū $\mathrm{z}<\overline{\mathbf{1}}>\overline{1}$ t cašmainī vī.adarəsəm,

vayhōuš mainiiōuš š́iiaoưnahiiā uxóax́iiācā

vīduš așāa yōm Mazdąm Ahurəm;

at hōi vahmōṇng dəmānē garō ni.dāmā;

9 tōm nō Vohū mat Manạhā cixšnušō, yō nō usōn cōrột spōṇcā aspōṇcā, mazdå xšaưrā; varəzī nå diiāt Ahurō pasūš vīrōṇg ahmākōṇg fradavaàiiā vạhōuš aṣ̆ā haoząựāt à manayhō;

10 tōm nō yasnāiš ārmatōiš mimaү̌̌žō, yō ąnmōnī Mazdå srāuuī Ahurō.

hiiaț hōi așāa vohūcā cōišst manayhā, xšaưrōi hōi hauruuātā amərətātā ahmāi stōi dąn, touuīšī utaiiūitī.

11 yas.tā daēuuōṇ aparō maṣ̆iiąscā tarō.mąstā yōi īm tarō.mainiiaṇtā (aniiōṇg ahmāt, yō hōi arōm mainiiātā), saošiiaṇtō dōṇg patōiš spoṇtā daēnā uruuāôō brātā ptā vā, Mazdā Ahurā. 


\section{Yasna 46}

1 kąm nəmōi ząm, kư̛rā nəmōi aiienī? pairī x $x^{\mathrm{V} a e ̄ t o ̄ u s ̌ ~ a i r i i a m n a s c a ̄ ~ d a d a i t i ̄ ; ~}$ nōit mā xšnāuš, yā vərəzōnā hōcā, naēdā dax́iiōuš yōi sāstārō drəguuaṇtō. kaūā ởā, Mazdā, xšnaošāi, Ahurā?

2 vaēeā taț yā ahmī, Mazdā, anaēšō: mā kamna.fšuuā hiiațcā kamnā.nā ahmī. gərəzōi tōi: ${ }^{101}$ ā î̀ [ā] vaēnā, Ahurā, rafeôrōm caguuå hiiat friiō friiāi daidìt: ā.xsō vayhōuš așaa i ištìm manayhō.

3 kadā, Mazdā, yōi uxšānō asnąm anhōuš darəưrāi frō aṣ̆ahiiā [fr]āroṇtē vərəzdāiš sōṇghāiš, saošiiaṇtąm xratauuō? kaēibiiō ūōāi vohū jimat mananhā? maibiiō ơßā sąstrāi vərənē, Ahurā.

4 at tōng droguuå yōng aṣ̆ahiiā važdrōṇg pāt gå frōrətōiš šōiưrahiiā vā dax́iiōuš vā, dužazōbå hąs, xvāiš š́iiaoưnāiš ahōmustō. yas.tōm xšaưrāt, Mazdā, mōiơa jiāātōuš vā, huuō tōṇg frō gå paưmōṇg hucistōiš carat.

5 yō vā xšaiiąs ā dąm ${ }^{102}$ drìtā aiiaṇtom uruuātōiš vā huzōṇtuš miưrōibiiō vā, rašnā juuąs, yō aș̆auuā drəguuaṇtəm, vīcirō hąs, tat frō $x^{\mathrm{V} a e ̄ t a u u e ̄ ~ m r u i i a ̄ a t ~}$ uz.ūiơiiōi īm, Mazdā, xrūniiāă, Ahurā.

6 at yas.tōm nōit nā isømnō à ā.iiāt, Drūjō huuō dāmąn haēôahiiā gāt; huuō zī drøguuå, yō drøguuāitē vahištō, huuō aṣ̆auuā, yahmāi așauuā friiō, hiiat daēnå paouruiiå då, Ahurā.

7 kōm.nā, Mazdā, mauuaitē pāiiūm dadå, hiiat mā dreguuå dīdarəšatā aēnańhē, aniiōm ơßahmāt āôrascā manayhascā, yaiiå šiiaoưnāiš aș̆øm Ưraoštā, Ahurā? tąm mōi dąstuuąm daēnaiiāi frā.uuaocā. 
8 yō vā mōi yå gaēơå dazdē aēnaýhē, nōit ahiiā mā āơriš š́iiaoûnāiš frā asiiāta ${ }^{103}$ paitiiaogot tā ahmāi jasōit duuaēšayhā tanuuōm ā, yā īm hujiiātōiš pāiiāt, nōit dužjiiātōiš̆; kācīt, Mazdā, duuaēšanhā.

9 kō huuō, yō mā arədrō cōiơat paouruiiō, yaùā ơßā zəuuištīm uz.ōmōhī, šiiaoûnōi spəntəm, Ahurəm aṣ̆auuanəm? yā tōi Aș̣ā, yā Aș̣āi gōuš tašā mraoț, išəṇtī mā tā tōi vohū manayhā?

10 yō vā mōi nā gənā vā, Mazdā Ahurā, dāiiāt ạhōuš yā tū vōistā vahištā, aș̣ìm așaāi, vohū xšav̛rom manayhā, yąscā haxšāi xšmāuuatąm vahmāiiā, frō tāiš vīspāiš Cinuuatō [fra]frā pərətūm.

11 xšaưrāiš yūjōn Karəpanō Kāuuaiiascā akāiš š́iiaoûnāiš ahūm mərəngəidiiāi maṣ̌īm;

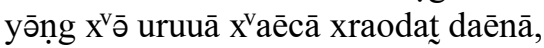
hiiat aibī.gəmən yaưrā Cinuuatō pərətuš, yauuōi vīspāi Drūjō dəmānēe $\overline{-1}^{-104}$ astaiiō.

12 hiiat us aṣ̆ā naptiiaēšū nafšucā Tūrahiiā [uz]jōn Friiānahiiā aojiiaēšū ārmatōiš gaēơå frādō ơßaxšạhā, at îš vohū hōm aibī.mōist manayhā aēibiiō rafớrāi Mazdå sastē Ahurō.

13 yō Spitāməm Zaraưuštrəm rādạhā martaēšū xšnāuš, huuō nā fra.srūidiiāi ərəơßō. at hōi Mazdå ahūm dadāt Ahurō; ahmāi gaēơå vohū frādat manayhā; tōm vō Aṣ̆ā mōhmaidī hušhaxāim.

14 “ZaraƯuštrā, kas.tē așauuā uruuāôō mazōi magāi? kō vā fra.srūidiiāi vaštī?’" at huuō kauuā Vištāspō, yā <a $>$ hī. ${ }^{105}$ yōṇgs.tū, Mazdā, hadəmōi minaš, Ahurā, tōṇg zbaiiā vạhōuš uxōāiš manayhō.

15 Haēcat.aspā, vaxšiiā vō, Spitamånhō: hiiat dāôōng vī caiiavaā adāôąscā,

103 Humbach: fərōsiiāt vel fraōsiiāt libri

104 Insler: dəmānāi $\omega$

$105<>$ Insler 
tāiš yūš šiiaoônāiš aș̌əm xšmaibiiā daduiiēe, ${ }^{106}$

yāiš dātāiš paouruiiāišs Ahurahiiā

16 Frašaoštrā, aưrā tū arədrāiš idī,

Huuōguuā, tāiš yōṇg usuuahī uštā stōi, yaưrā așā hacaitē ārmaitiš, yaưrā vạhōuš manayhō ǐštā xšaơrəm, yaưrā Mazdå varədəmąm š́aēitī Ahurō,

17 yaưā vō afšmānī sōṇghānī, nōit anafšmąm, Dōjāmāspā Huuōguuā, hadā vō stōi ${ }^{107}$ vahmōṇg sraošā rādayhō, yō vī.cinaoț dā daṇgrā maṇtū Aṣ̆ā, Mazdå Ahurō.

18 yō maibiiā yaoš, ahmāi ascīi vahištā max́iiå ištōiš vohū cōišəm manayhā, ąstōṇg ahmāi yō nå ąstāi daidītā, Mazdā Așā, xšmākəm vārəm xšnaošəmnō; tat mōi xratōuš manayhascā vī.cið̀əm.

19 yō mōi așaãt haiồim hacā varəšaitī Zaraưuštrāi hiiat vasnā frašōtəməm, ahmāi mīždəm hanəṇtē parā. $<\mathrm{a}>$ hūm manō.vistāiš mat̃ vīspāiš, gāuuā azī: tācīt mōi sąs tuuōm, Mazdā, vaēdištō.

\section{Yasna 47}

1 spəṇtā mainiiū vahištācā manayhā hacā așaã š́iiaoưnācā vacạhācā ahmāi dąn hauruuātā amərətātā; mazdå xšav̂rā Ārmaitī Ahurō.

2 ahiiā maniiōuš spōništahiiā vahištəm hizuuā uxōāiš vạhōuš ōoānū manạhō, ārmatōiš zastōibiiā š́iiaoûnā vərəziiat, ōiiā cistī, "huuō ptā Aṣ̆ahiiā Mazdå".

3 ahiiā maniiōuš tuuōm ahī $<\mathrm{p}>$ tā spoṇtō, yō ahmāi gąm rāniiō.skərətīm hōm.tašaț. at hōi vāstrāi rāmā då ārmaitīm, hiiat hōm Vohū, Mazdā, [hōm]fraštā Manayhā. 
4 ahmāt mainiiōuš rārəšiieiṇtī drəguuaṇtō, Mazdā, spoṇtāt; nōit iỡa $\bar{\sim}^{108}$ așauuanō. kasōušcīt nā așāunē kāôō ayhat, isuuācīt hąs paraoš akō droguuāitē.

5 tācā spəṇtā mainiiū, Mazdā Ahurā, așāunē cōiš yā zī cīcā vahištā; hanarə ৩̛ßahmāt zaošāt drəguuå baxšaitī, ahiiā š́iiaoûnāiš akāt ā š́iiąs manạhō.

6 tā då spontā mainiiū, Mazdā Ahurā, āơrā vạhāu vī.dāitīm rānōibiiā ārmatōiš dəbązayhā aṣ̆ax́iiācā; hā zī pourūš išəṇtō vāurāitē.

\section{Yasna 48}

1 yezī at āišs ${ }^{109}$ Așā Drujom vōṇghaitī, hiiat †ąsaṣ̆utā ${ }^{110}$ yā daibitānā fraoxtā amərətāitī daēuuāišcā mașiiāišcā, at tōi sauuāiš vahməm vaxšat, Ahurā.

2 vaocā mōi a $\bar{a}^{111}$ — tuuōm vīduuå, Ahurāparā hiiat mā yāmōṇg ${ }^{112}$ pərəôā jimaitī: kat așauuāa, Mazdā, vōṇghat drəguuaṇtəm? hā zī ạhōuš vay'hī vistā ā.kərətiš.

3 aț vaēdəmnāi vahištā sāsnanąm, yąm hudå sāstī așāa ahurō, spəṇtō, vīduuå yaēcīt gūzrā sōṇghånhō, ởàuuąs, Mazdā, vạhōuš xrav̛ßā manayhō.

4 yō dāt manō vahiiō, Mazdā, aš́iiascā, huuō daēnąm š́iiaoưnācā vacạhācā, ahiiā zaošōṇg uštīš varənōṇg hacaitē; ৩̛ßahmī xratāu apōməm nanā ayhaț.

5 huxšav̛rā xš̄̄ṇtąm-mā nō dušxšavorā xšōṇtāvạhuiiå cistōiš š́iiaovanāiš, Ārmaitē. yaož.då mașiiāi aipī ząưom vahištā gauuōi vərəziiātąm: tąm nō xVarəôāi fšuiiō.

\footnotetext{
108 m s: aūā $h v$

109 Insler, Narten: adāiš $\omega$ (akāiš B)

110 fort. ąsat tā

111 Kuiper: mōi yā $\omega$

112 Insler: yā mōṇg $\omega$
} 
6 hā zī [nō] hušōiờmā, ${ }^{113}$ hā nō utaiiūitîi ${ }^{114}$

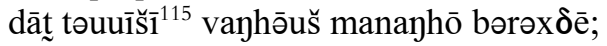
at ax́iiāi aș̆ā Mazdå uruuārå vaxšat Âhurō ayhōuš ząōōi paouruiiehiiā.

7 nī aēšmō [nī] diiātąm, paitī rəməm [paitī] siiōdūm, yōi ā vayhōuš manayhō dīdra ₹̌̌̌ōduiiē.

ašā viiąm, yehiiā hiơāuš nā spəṇtō:

at hōi dāmąm ơßahmī ā dąm, Ahurā.

8 kā tōi vạhōuš, Mazdā, xšaưrahiiā īštišs?

kā tōi aṣ̆oiš ơßax́iiå maibiiō, Ahurā?

kā ơßōi, Aṣ̆ā ākå arədrōng išiiā,

vâhว̄uš mainiiōuš š́iiaoùnanąm jauuarō?

9 kat a $\bar{a}^{116}$ vaēdā, yezī cahiiā xšaiiaùā,

Mazdā Aṣ̆ā, yehiiā mā āiơiš duuaēôā?

ərəš mōi [ərəž] ūcąm vạhōuš vafuš manayhō;

vīdiiāt saošiiąs, yavoā hōi aș̌iš ayhat.

10 kadā, Mazdā, mąnarōiš narō vīsøṇtā? ${ }^{117}$

kadā a.jōn mūưrəm ahiiā madahiiā, yā aṇgraiiā Karəpanō urūpaiieiṇtī yācā xratū dušxšaưrā dax́iiunąm?

11 kadā, Mazdā, Aș̆ā mat Ā Ārmaitiš jimat xšaưrā huš̀itiš vāstrauuaitī? kōi drəguuōdəbīš xrūrāiš rāmąm dåṇtē? kōṇg à vayhōuš jimat manayhō cistišs?

12 at tōi ayhon saošiiaṇtō dax́iiunąm, yōi xšnūm vohū manayhā hacåṇtē šiiaoûnāiš așaā ơßahiiā, Mazdā, sōṇghahiiā;

tōi zī dātā hamaēstārō aēšmahiiā.

\section{Yasna 49}

1 at mā yauuā bōṇduuō pafrē mazištō, yō dušərəơrīš cixšnušā așāā, Mazdā.

Vay'hī Ādā, gaidī mōi, à mōi [a]rapā:

ahiiā vohū aošō vīdā manayhā.

113 [] Lommel hu- s: u- $m h v$

$114 s$ : utaiiūitīm $m h v$

115 dett.: təuūīšīm $m h s v$

$116 s$ : kadā $m h$ H: kav̄ā $G$

117 vīsoṇtā $A$ : -ṇtē $B h E$, -ṇti $F$ 
2 at ahiiā mā bōṇduuahiiā mānaiieitī

tkaēšō drəguuå daibitā așẵã rārəšō:

nōit spoṇtąm dōrəšt ahmāi stōi Ārmaitīm, naēdā Vohū, Mazdā, fraštā Manayhā.

3 ațcā ahmāi varənāi, Mazdā, ni.dātəm ašəm sūidiiāi, tkaēšāi rāšaiieńhē druxš. tân $^{118}$ vayhōuš sarō iziiāi manayhō; aṇtarō vīspōṇg drəguuatō haxmōṇg [aṇtarō] mruiiē.

4 yōi dušxravßßa aēšməm varədən rəməmcāa ${ }^{119}$ X $\mathrm{v}$ àiš hizubī̌̆, fšuiiasū afšuiiaṇtō, yaēšąm nōit huuarštāiš vąs dužuuarštā, tōi daēuuōṇg dąn, yā droguuatō daēnā.

5 at huuō, Mazdā, īžācā āzūitišcā, yō daēnąm vohū sārštā manạhā, ārmatōiš kascīt așā huzōṇtuš, tāišcā vīspāiš ơßahmī xšaưrōi, Ahurā.

6 frō vå [fra]išiiā, Mazdā Aṣ̆ømcā, mrūitē, yā vō xratōuš xšmākahiiā ā manayhā, ərəš vî.cidiiāi, yaûā 1 srauuaiiaēmā tąm daēnąm yā xšmāuuatō, Ahurā.

7 tatcā vohū, Mazdā, ${ }^{120}$ sraotū manayhā, sraotū așāa: gūšahuuā tū, Ahurā: kō airiiamā, kō xvaētuš dātāiš ayhat, yō vərəzōnāi vạไhīm dāt frasastīm?

8 Frašaoštrāi uruuāzištąm aș̆ahiiā då sarōm — tat ơßā, Mazdā, yāsā, Ahurāmaibiiācā, yąm vayhāu ơßahmī à xšaơrōi; yauuōi vīspāi fraēštånhō ånhāmā.

9 sraotū sāsnå fšōýhiiō suiiē taštōnōit ərəš.vacå sarōm didąs drəguuātāhiiat daēnå vahištē yūjōn mīždē ašā yuxtā yāhī Dōjāmāspā.

10 tatcā, Mazdā, ơßahmī ā dąm ni.påńhē: manō vohū urunascā așāunąm nəmascā, yā ārmaitiš īžācā mązā.xšaưrā vazdayhā †auuōmīrā.

118 fort. $\mathrm{ta} \overline{\mathrm{a}}<\overline{\mathrm{a}}>, c f . \$ 300$

119 Insler: rāməmcā $\omega$

120 Mazdå Westergaard 
11 at dušxšaơrōṇg dušš́iiaoônōṇg dužuuacạhō duždaēnōṇg dušmanayhō drəguuatō akāiš x ${ }^{\mathrm{V}}$ arəơāiš paitī uruuąnō [paiti]yeiṇtī; Drūjō dəmānē haiviiiā ạhən astaiiō.

12 kat tōi așā zbaiieṇtē auuạhō Zaraùuštrāi? kat tōi vohū manayhā, yō vō staotāiš, Mazdā, frīnāi, Ahurā, auuat yāsąs, hiiat vō īštā vahištəm?

\section{Yasna 50}

1 kat mōi uruuā isē cahiiā auuayhō? kō mōi pasōuš, kō mōnā Ưrātā vistō aniiō aș̆ãa ởatcā, Mazdā Ahurā, azdā zūtā, vahištāațā manayhō?

2 kav̄ā, Mazdā, rāniiō.skərətīm gąm išasōit, yō hīm ahmāi vāstrauuaitīm stōi usiiāt, ərəž.jīš așāa pourušū huuarō piš́iiasū? akąs tōṇg ${ }^{121}$ mā niš ąsiiā, dāô̄ōm dāhuuā.

3 atcīt ahmāi, Mazdā, aṣ̆ā ạhaitī, yąm hōi xšaưrā vohūcā cōišst manayhā, yō nā aș̆ōiš aojạhā varədaiiaētā, yąm nazdištąm gaēoạm drəguuå baxšaitī.

4 at̃ vå yazāi stauuas, Mazdā Ahurā, hadā așā vahištācā manayhā xšaưrācā yā īšō stånhat ã paiời; ākå arədrōṇg dəmānē garō sraošānē.

5 ārōi zī xšmā, Mazdā Aṣ̄ā Ahurā, hiiat yūšmākāi mąưrānē vaorāzaṽā aibī.dərəštā āuuīšiiā auuạhā zastā.ištā, yā nå x $\mathrm{V}$ āôrē dāiiāt,

6 yō mąưrā vācom, Mazdā, baraitī uruuāôō așā nəmayhā, Zaraưuštrō. dātā xratōuš, hizuuō raiồim stōi mahiiā, rāzōṇg vohū sāhīt manạhā.

7 at vō yaojā zouuištiiōṇg auruuātō, jaiiāiš pərəơūšš ${ }^{122}$ vahmahiiā yūšmākahiiā, 
Mazdā Aṣ̆ā, ugrōṇg vohū manayhā, yāiš <z>azāôā: ${ }^{123}$ mahmāi x́iiātā auuańhē.

8 mat vå padāiš yā fra.srūtā īžaiiå pairi.jasāi, Mazdā, ustāna.zastō, at vå așā arədrax́iiācā nəmayhā, at vå vayhōuš manayhō hunarotātā.

9 tāiš vå yasnāiš paitī stauuas aiienī, Mazdā Aș̣ā, vayhōuš š́iiaoưnāiš manayhō. yadā ašōiš max́iiå vasō xšaiiā, at hudānaoš išaiiąs gərəzdā x́iiōm.

10 at yā varəšā yācā pairī àiš š́iiaoưnā yācā vohū cašmąm arəjat manạhā, raocå $\mathrm{x}^{\mathrm{v}}$ ōng, asnąm uxšā aēuruš, xšmākāi aṣā vahmāi, Mazdā Ahurā.

11 at vō staotā aojāi, Mazdā, ạhācā, yauuat așāa tauuācā isāicā. dātā ạhōuš arədat vohū manayhā haiviiiā.varštąm, hiiat vasnā frašōtəməm?

\section{Yasna 51}

1 vōhū xšaưrəm vairīm, bāgəm aibī.bairištom vīdīšəmnāi ${ }^{124}$ īžācīt; așā aṇtarə.caraitī š́iaoưnāiš, Mazdā, vahištəm: tat nō nūcīt varəšānē.

2 tā vō, Mazdā, paouruuīm, Ahurā, Aṣ̆āiiecā taibiiācā, Ārmaitē, dōišā mōi ištōiš xšaưrəm; xšmākəm vohū manạhā vahmāi dāidī sauuạhō.

3 ā vō gōušā hōm.iiaṇtū, yōi vō š́iaoưnāiš sārøṇtē, Ahurā ${ }^{-125}$ Așāa hizuuā ${ }^{126}$ uxōaišs vayhōuš manạhō, yaēšąm tū paouruiiō, Mazdā, fra.daxštā ahī.

4 kuơrā ārōiš ā fsəratuš, kuơrā mərəždikāa ${ }^{127}$ à xštaț? kuƯrā yasō.x́iiōn așॅəm? kū spəṇtā ārmaitišs? kuƯrā manō vahištom? kựrā ởā xšaưrā, Mazdā?

$123<>$ Humbach

124 m D: -mnāiš $C s v$

125 West: ahurō $\omega$

$126 B h$ : hizuuō $A$ : hizuuå $s v$

127 m C s: -kāi $D$ v 
5 vīspā tā pərəsā, ${ }^{128}$ yaưā așaāt hacā gąm vīdaț vāstriiō š́iiaoûnāiš ərəšuuō, hąs huxratuš, nəmayhā, yō dāơaēibiiō ərəš.ratūm xšaiiąs aṣ̆iiå ${ }^{129}$ cistā.

6 yō vahiiō vayhōuš dazdē, yascā hōi vārāi rādat, Ahurō xšaưrā mazdå; at ahmāi akāt aš́iiō, yō hōi nōit vīdāitī, apōmē ạhōuš uruuaēsē.

7 dāidī mōi, yō gąm tašō apascā uruuāråscā, amərətātā hauruuātā spōništā mainiiū, Mazdā, təuūîši utaiiūitī manạhā vohū sōńhē.

8 at zị tōi vaxšiiā, Mazdā-vīdušē zī nā mruiiāt hiiat akōi a ${ }^{-130}$ drəguuāitē, uštā yō aṣ̌əm dādrē (huūō zī mąưrā šiiātō, yō vīdušē mrauuaitī)

9 yąm xšnūtom rānōibiiā då ơßā āôrā suxrā, Mazdā, aiianhā xšustā, aibī ahuuāhū daxštom dāuuōi, rāšaiieńhē drəguuaṇtəm, sauuaiiō aș̆auuanəm.

10 at yō mā nā maroxšaitē aniiāơā ahmāt, Mazdā, huuō dāmōiš drūjō hunuš; tā duždå, yōi həṇtī. maibiiō zbaiiā aṣ̆em vayhuiiā aṣ̆i gatē.

11 kō uruuāôō Spitamāi ${ }^{131}$ Zaraưuštrāi nā, Mazdā? kō vā Aṣāa afraštā? ${ }^{132}$ kā spəṇtā ārmaitišs? kō vā vayhōuš manayhō acistā magāi ərəšuuō?

12 nōit tā īm xšnāuš vaēpiiō kəuuīnō pərətå zimō Zaravิuštrəm Spitāməm, hiiat̃ ahmī urūraost aštō, hiiat hōi $\overline{1}[\mathrm{~m}]^{133}$ caratascā aodərəšcā zōišnū vāzā.

13 tā drəguuatō marədaitī daēnā ərəzaoš haiôīm; yehiiā uruuā xraodaitī Cinuuatō pərətå ākå,

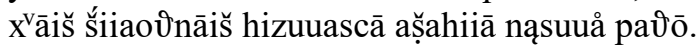

14 nōit uruuāôā dātōibiiascā Karəpanō vāstrāt arōm, gauuōi ārōiš ā.sōṇdā xª̄iš š́iiaoûnāišcā sōnghāišscā; yō îš sōṇghō apōmom Drūjō dəmānē ā.dāt.

128 West: pərəsąs $\omega$

129 aṣ̆iå $E$ : aș̆auuå $m F$ : aṣ̆iuuå $h G$

130 akōiiā $\omega$

131 spitamāii $<\overline{\mathrm{a}}>$ Beekes

132 det.: āfraštā $m h v$, ā.fraštā $s$

133 [] Insler 
15 hiiat mīždəm Zaraưuštrō magauuabiiō cōišt parā, garō dəmānē Ahurō Mazdå jasat paouruiiō:

tā vō Vohū Manayhā Așaāicā sauuāiš couuīšī.

16 tąm kauuā Vištāspō magahiiā xšaưrā nąsat vạhōuš padəbīš manayhō, yąm cistīm aṣ̆ā maṇtā:

"spəṇtō Mazdå Ahurō", aưā nō sazdiiāi uštā.

17 bərəxốąm mōi Frašaoštrō Huuōguuō daēdōišt kəhrpōm daēnaiiāi vạhuiiāi; yąm hōi išiiąm dātū xšaiiąs Mazdå Ahurō, Aṣ̆ahiiā āždiiāi gərəzdīm.

18 tąm cistīm Dōjāmāspō Huuōguuō ištōiš $\mathrm{x}^{\mathrm{V}}$ aronå aṣ̆ā vərəṇtē, tat xšaưrəm manạhō vạhōuš vīdō. tat hōi ${ }^{134}$ dāidī, Ahurā, hiiat, Mazdā, rapōn tauuā.

19 huuō tat nā, Maidiiōimånhā Spitamā, ahmāi dazdē daēnaiiā vaēdəmnō, yō ahūm išasąs aibī Mazdå dātā mrauuaț ${ }^{135}$ gaiiehiiā š́iiaoûnāiš vahiiō.

20 tẫ vō nō, hazaošånhō vīspånhō, daidiiāi sauuō, Ašəm vohū manayhā uxōā, yāiš ārmaitiš, yazəmnåyhō nəmayhā Mazdå rafəôrəm cagədō.

21 ārmatōiš nā, spəṇtō huuō cistī, uxōāiš, š́iiaoônā, daēnā; aș̌m spōnuuat, vohū xšaưrəm manayhā Mazdå dadāt Ahurō: tōm vay'hīm yāsā aṣ̆īm.

22 yehiiā mōi aṣ̆ăt hacā vahištom yesnē paitī, vaēdā: Mazdå Ahurō. yōi ånharəcā həṇticā, tą ${ }^{136}$ yazāi xvāiš nāmōnīšs ${ }^{137}$ pairicā jasāi vạ̣tā.

\section{Yasna 53}

1 vahištā îštiš srāuūi Zarađušstrahē Spitāmahiiā, yezī hōi dāt àiiaptā așaâa hacā Ahurō Mazdå yauuōi vīspāiiā, huuayhəuuīm, yaēcā hōi dabən saškəṇcā ${ }^{-138}$ daēnaiiå vayhuiiå uxōā š́iiaoûnācā.

2 atcā [hōi $]^{139}$ scantū mananhā uxôaiš š́iiaoơnāišcā xšnūm Mazdå ${ }^{140}$ vahmāiia fraorəț yasnąscā,

\footnotetext{
134 West: mōi $\omega$

135 West: mraot $\omega$

$136 h v$ : tąm $m$ s: eaedem vv.ll. Y. 15. 2, 63. 1, 65. 16, 69. 1

137 nāməb̄̄š Schwyzer

138 saškṇcā $D$, saškəmcā $s$ : saš́ącā $m$, saš́ṇcā $C v$

139 [ ] Kellens-Pirart

140 s v: mazdā $A D$, -āi $B C$
} 
kauuacā Vī̌stāspō Zaraưuštriš Spitāmō Frašaoštrascā, dåyhō ərəzūš paūō, yąm daēnąm Ahurō saošiiaṇtō dadāt.

3 tōṇcāa ${ }^{141}$ tū, Pourucistā Haēcat.aspānā

Spitāmī, yezuuī dugədrąm Zaraưuštrahē:

vanhōuš tpaitiiāstīm ${ }^{142}$ mananhō așahiiā Mazdåscā taibiiō dāt sarəm.

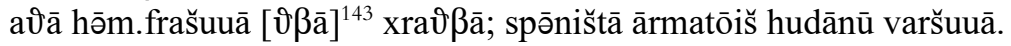

4 tōm zī vō †spərədānī varānī†, yā fəôrōi vīdāt

paiv̛iiaēcā vāstriiaēibiiō atçā $x^{\mathrm{V} a e ̄ t a u u e \overline{,}}$

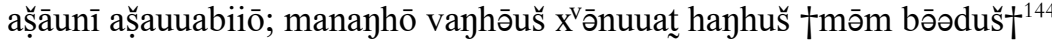

Mazdå dadāt Ahurō daēnaiiāi vạhuiiāi yauuōi vīspāiiā.

5 sāx $x^{v}$ ōn vaziiamnābiiō kainibiiō mraomī xšmaibiiācā, vadəmnā: ${ }^{145}$ mōṇcā 1 [mąz]dazdūm, vaēdōdūm daēnābīš abiiascā ahūm yō vayhōuš mananhō. aṣ̆ā vō aniiō ainīm vīuuōnghatū: taț zī hōi hušōnəm ayhat.

6 iơā 1 haiơiiāa, narō, ađāa, jōnaiiō. drūjō hacā rāờmō yōm spašữā ${ }^{146}$ frāidīm

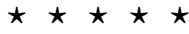

$\star$ drūjō: à.iiesē †hōiš piơā $\dagger^{147}$ tanuuō parā.

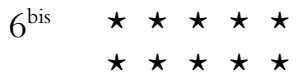

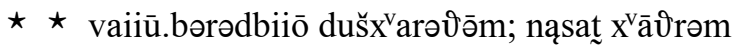

drəguuōdəbiiō dōjīîn.arətaēibiiō. anāiš ā manahīm ahūm mərəngeduiiē.

7 ațcā vō mīždəm anhat ahiiā magahiiā:

yauuat āzuš zrazdištō būnōi haxtiiå

parā[cā̄] ${ }^{148}$ mraocąs aorācā, yaưrā mainiiuš droguuatō anąsat ${ }^{149}$ parā.

vī.zaiiaưā magōm tōm, at vō "vaiiōì" ahhaitī apōməm vacō.

8 anāiš à dužuuaršnanhō dafšniiā hōntū

zax́iiācā vīspånhō, xraosəṇtąm upā,

huxšaưrāiš jōnərąm xrūnərąm[cā], rāmąmcā āiš dadātú š́iieitibiiō vīžibiiō; îratū îs duuafšō huuō dərəzā mərəviiiaoš mazištō; mošucā astū!

\footnotetext{
141 Insler: tīmcā $m$, tōmcā $h s v$

142 paitiiāstīm $m v$, -stōm $h$ s: disyllabo opus est

143 [] Kellens-Pirart

144 mōn.bōnduš Humbach

145 fort. vadømnånhō

146 spaš $<$ n > uṽā Humbach

147 pađ̄ā $D H$, pōiơā $A a$

148 [] Monna

149 ā nąsāt Insler
} 
9 dužuuarənāiš vaēšō rāstī; tōi narəpī̌s rajī̌s $\breve{s}^{150}$ aēšasā dōjīt.arətā, pəș̆ō.tanuuō.

kū așauuā ahurō, yō īš jiiātōuš hōm.miviiiāt vasō.itōišcā?

tat, Mazdā, tauuā xšaưrəm, yā ərəžə.jiiōi dāhī drigauuē vahiiō.

\section{Yasna 54}

1 à Airiiōmā išiiō rafəơrāi jaṇtū ${ }^{151}$

nərəbiiascā nāiribiiascā Zaraưuštrahē, vạhōuš rafəơrāi manạhō, yā daēnā vairīm hanāt mīždəm. aṣ̆ahiiā yāsā aṣ̌ịm, yąm išiiąm Ahurō masatā Mazdå.

\section{B. The Yasna Haptayhāiti}

\section{Yasna 35}

2 humatanąm hūxtanąm huuarštanąm iiadacā aniiadacā vərəziiamnanąmcā vāuuərəzananąmcā mahī aibī.jarətārō: naē naēstārō yaưənā vohunąm mahī.

3 tat at varomaidī, Ahurā Mazdā Aș̣ā srīrā, hiiat î mainimadicā vaocōimācā varəzimācā, yā hātąm š́iiaov̀ənanąm vahištā xiiāẫ ubōibiiā ahubiiā.

4 gauuōi at àišs ${ }^{152}$ tāiš š́iiaov̀onāiš yāiš vahištāiš fraēšiiāmahī rāmācā vāstrəmcā dazdiiāi srunuuatascā asrunuuatascā xšaiiaṇtascā axšaiiaṇtascā.

5 huxšaưrōtəmāi bā at xšaưrəm, ahmat hiiat aibī, dadəmahicā cīšmahicā huuąnmahicā, hiiat Mazdāi Ahurāi Aș̆āicā vahištāi.

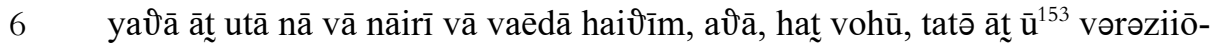

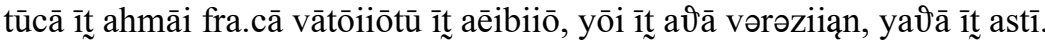

7 Ahurahiiā zī at [vō] Mazdå ${ }^{154}$ yasnəmcā vahməmcā vahištom amōhmaidī, gōušcā vāstrəm. tat at vō vərəziiāmahī fra.cā vātōiiāmahī, yātō isāmaidē.

8 Aṣ̆ahiiā āat sairī, Aș̆ahiiā vərəzōnē kahmāicīt hātąm jījišąm vahištąm ādā ubōibiiā ahubiiā.

9/10 imā āt uxōā vacå, Ahurā Mazdā, Aṣ̆əm manaiiā ${ }^{155}$ vahehiiā fra.uuaocāmā: ৩̛ßąm at aēšąm paitiiāstārəmcā fra.daxštārəmcā dadəmaidē, (10) Aṣ̆āațcā

$150 C v$, rijī̌s $m:$ arojī̌s $D E$, -zī̌s $F$

151 fort. rafəôrāii $<\bar{a}>$ vel $<\bar{a}>$ jaṇtū

152 Insler, Narten: adāiš $\omega$

153 Narten: tat ōoādū fere $\omega$

154 [] West mazdå $m h v$ : mazdā $s$

155 dett.: manahiiā $m$ : maniiā $D F$, mainiiā $C E v$ 
hacā Vanhōušcā Manayhō Vanhōušcā Xšađ̛rāt, staotāiš ơßāt [Ahurā] ${ }^{156}$ staotōibiiō aibī, uxōā ợāt uxōōibiiō, yasnā ợāt yasnōibiiō.

\section{Yasna 36}

1 ahiiā ởā āơrō vorəzōnā paouruiiē pairi.jasāmaidē, Mazdā Ahurā, ơßā ơßā mainiiū spōništā, yō ā axtiš ahmāi, yōm axtōiiōi dånhē.

2 uruuāzištō huuō nå ${ }^{157}$ yātāiiā paitī.jamiiå, Ātarə Mazdå Ahurahiiā, uruuāzištahiiā uruuāziiā, nąmištahiiā nəmanhā nå mazištāi yånhąm paitī.jamiiå.

3 ātarš vōi Mazdå Ahurahiiā ahī, mainiiuš vōi ahiiā spōništō ahī; hiiat vā tōi nāmanąm vāzištom, Âtarə Mazdå Ahurahiiā, tā ơßā pairi.jasāmaidē.

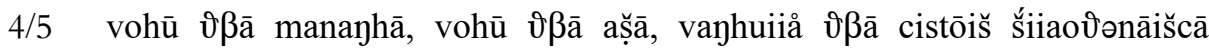
vacōbīšcā pairi.jasāmaidē (5) nəmax́iiāmahī išūidiiāmahī ơßā, Mazdā Ahurā; vīspāiš ởā humatāiš, vīspāiš hūxtāišs, vīspāiš huuarštāiš pairi.jasāmaidē.

6 sraēštąm at tōi kəhrpōm kəhrpąm ā.uuaēdaiiamahī, Mazdā Ahurā, imā raocå; barəzištəm barəzimanąm auuat yāt huuarə ${ }^{158}$ auuācī.

\section{Yasna 37}

1/3 iơā ẫ yazamaidē Ahurəm Mazdąm, yō gąmcā aṣ̆əmcā dāt, apascā dāt uruuaråscā vạ'hīš, raocåscā dāt būmīmcā vīspācā vohū, (2) ahiiā xšaưrācā mazōnācā hauuapanhāišsā.

tōm at yasnanąm pauruuatātā yazamaidē, yōi gōuš hacā š́iieiṇtī; (3) tōm at āhūiriiā nāmōnī mazdā.varā spəṇtōtomā yazamaidē; tōm ahmākāiš azdøbīscā uštānāišcā yazamaidē; tōm aṣ̆āunąm frauuaṣ̆iš narąmcā nāirinąmcā yazamaidē.

4 Aṣ̆om at vahištom yazamaidē, hiiat sraeštom, hiiat spoṇtom, < <iiat > $>159$ aməṣ̆əm, hiiat raocōyhuuat, hiiat vīspā.vohū;

5 Vohucā Manō yazamaidē, Vohucā Xšaưrom, Vay'hīmcā Daēnąm, Vay'hīmcā Fsøratūm, Vay'hīmcā Ārmaitīm.

156 [ ] West

$157 s v$ : nā $m h$

158 huuarō $m h$, -ə H: auuarō $s G$

$159<>$ West 


\section{Yasna 38}

1/2 imąm āą Ząm Gənābīš haơrā yazamaidē: yā nå baraitī yåscā tōi gənā, Ahurā Mazdā, aș̆āt hacā vairiiå, tå yazamaidē, (2) Ižå Yaoštaiiō Fraštaiiō

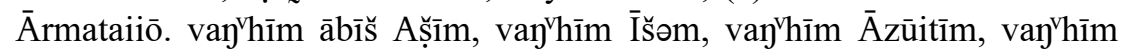
Frasastīm, vay'hīm Parə̣̣dīm yazamaidē.

3 Apō at yazamaidē maēkaiiaṇtīšcā hōbuuaṇtīšcā, frauuazạhō Ahurān̄̄š Ahurahiiā hauuapayhā. hupərəơßåscā vå huuō žavoåscā hūšnāơråscā ubōibiiā ahubiiā cagəmā.

4 ūitī, yā vō, vạ’hīš, Ahurō Mazdå nāmąm dadāt, vạhudå hiiat vå dadāț, tāiš vå yazamaidē, tāiš friiąnmahī, tāiš nəmax́iiāmahī, tāiš išūidiiāmahī.

5 apascā vå azī̌šcā vå mātərąšcā vå, agəniiå drigudāiiạhō vīspō.paitīš ā.uuaocāmā, vahištå, sraēštå. auuā vō, vayไhīš, rātōiš darəgō.bāzāuš nāšū paitī, viiādå, paitī.sōṇdå, mātarō jītaiiō.

\section{Yasna 39}

1/2 ivā āt yazamaidē gōuš uruuānəmcā tašānəmcā; ahmākōṇg āat urunō pasukanąmcā, yōi nå jījiš̌ṇtī, yaēibiiascā tōi ā, yaēcā aēibiiō ā ałhən, (2) daitikanąmcā aidiiūnąm hiiat urunō yazamaidē. aṣ̆āunąm āat urunō yazamaidē, kudō.zātanąmcīț, narąmcā nāirinąmcā, yaēšąm vahehīš daēnå vanaiṇtī vā vōṇghən vā vaonarə vā.

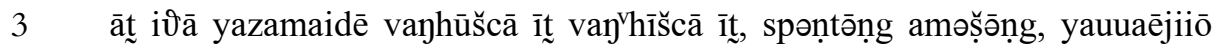
yauuaēsuuō, yōi vayhōuš ā manayhō š́ieiṇtī, yåscā ūitī.

4 yaưā tū $\overline{1}$, Ahurā Mazdā, mōṇghācā vaocascā dåscā varəšcā, yā vohū, aưā

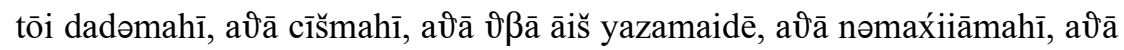
išūidiiāmahī ơßā, Mazdā Ahurā.

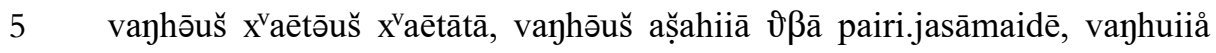
fsəratuuō, vayhuiiå ārmatōiš.

\section{Yasna 40}

1/2 āhū at paitī adāhū, Mazdā Ahurā, mazdąmcā būiricā kərəšuuā: rāitī tōi xrapaitī, ahmat hiiat aibī. hiiat mīždəm †mauuaiơom ${ }^{160}$ fra.dadav̄ā daēnābiiō, Mazdā Ahurā, (2) ahiiā huuō nō dāidī ahmāicā ahuiiē manaxiiāicā: tat ahiiā, yā tat upā.jamiiāmā, tauuacā haxəmā Aṣ̆axiiāaā vīspāi yauuē. 
3 dāidī at nərąš, Mazdā Ahurā, așāuunō aṣ̆a.cinạhō, aidiiūš vāstriiōṇg, darəgāi īžiiāi bəzuuaitē haxmainē ahmaibiiā ahmā.rafonayhō.

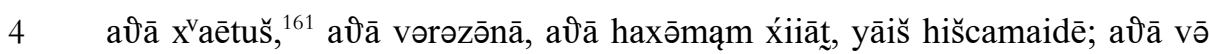
utā x́iiāmā, Mazdā Ahurā, aṣ̆auuanō ərəšiiāîn ${ }^{162}$ ištōm rāitī.

\section{Yasna 41}

1 stūtō, garō, vahmōṇg Ahurāi Mazdāi Aṣ̆āicā vahištāi dadəmahicā cīšmahicā ā.cā [ā]vaēdaiiamahī.

2 vohū xšaƯrəm tōi, Mazdā Ahurā, apaēmā vīspāi yauuē: huxšaưras.tū nō, nā vā nāirī vā, xšaētā ubōiiō ạhuuō, hātąm hudāstəmā.

3 humāīm ơßā, īžīm, yazatəm, aṣ̆ayhācim dadəmaidē. av̄ā tū nō gaiiascā astəṇtåscā x́iiå ubōiiō ạhuuō, hātąm hudāstəmā.

4 hanaēmācā zaēmācā, Mazdā Ahurā, ơßahmī rafonahī darøgāiiāu; aēšācā ơßā ōmauuaṇtascā buiiamā, rapōišcā tū nō darəgəmcā uštācā, hātąm hudāstəmā.

5/6 ৩̛ß̄oi staotarascā mąơranascā, Ahurā Mazdā, aogəmadaēcā usmahicā vīsāmadaēcā. hiiat mīždom †mauuaiơom fra.dadađ̄ā daēnābiiō, Mazdā Ahurā, (6) ahiiā huuō nō dāidī ahmāicā ahuiiē manax́iiāicā: tat ahiiā, yā tat upā.jamiiāmā, tauuacā haxəmā Aṣ̆ax́iiācā vīspāi yauuē.

161 xvaētuš $A E$ : -tūšs $B h v$ : x́aetōuš $F$

162 ərəšuuā dett. 
